\title{
The Impact of International Trade on Wage Gaps in Different Industries: An Empirical Study Based on China's Manufacturing Panel Data
}

\author{
Lingyan Ji \\ School of Business, Nanjing Normal University, Nanjing, China \\ Email: jly19940826@163.com
}

How to cite this paper: Ji, L.Y. (2019) The Impact of International Trade on Wage Gaps in Different Industries: An Empirical Study Based on China's Manufacturing Panel Data. Open Journal of Social Sciences, 7, 13-27.

https://doi.org/10.4236/jss.2019.73002

Received: January 31, 2019

Accepted: March 3, 2019

Published: March 6, 2019

Copyright () 2019 by author(s) and Scientific Research Publishing Inc. This work is licensed under the Creative Commons Attribution International License (CC BY 4.0).

http://creativecommons.org/licenses/by/4.0/ (c) (i) Open Access

\begin{abstract}
This paper classifies the panel data of 26 manufacturing industries in China from 2003 to 2014 according to different factors intensive industries, and conducts an empirical study on the impact of international trade on the wage gap within the industry by building a dynamic panel data model and using systematic GMM method. The study finds that, as far as the overall manufacturing industry is concerned, international trade will narrow the wage gap within the industry. If international trade is further divided into export trade and import trade, export trade will narrow the wage gap in the manufacturing industry as a whole, narrow the wage gap in labor-intensive industries, and narrow the wage gap in capital-intensive industries whose effect is not significant. However, the import trade will expand the wage gap in the manufacturing industry as a whole, narrow the wage gap in labor-intensive industries, and widen the wage gap in capital-intensive industries whose effect is not significant.
\end{abstract}

\section{Keywords}

International Trade, Wage Gap, Different Industries of Manufacturing, System GMM

\section{Introduction}

Although the phenomenon of anti-globalization began to emerge after the subprime mortgage crisis in America in 2008, economic globalization is still the mainstream of the world. Countries are still willing to participate in globalization and develop trade with other countries. In the process of globalization, de- 
veloping countries can undertake the production of foreign relatively high-tech industries, introduce foreign advanced technologies, learn advanced cultural knowledge and cultivate high-quality talents, which is conducive to the adjustment of domestic industrial structure. For developing countries, the deepening of trade and the reduction of trade barriers are conducive to exploring the international market and attracting foreign investment is conducive to the construction of domestic infrastructure. For developed countries, outsourcing the relatively low-technology industries can help the upgrading of domestic industries and save costs, so as to obtain higher benefits. The participation of developed countries in trade can also open up the international market and increase the international competitiveness of products. One of the reasons for the occurrence of anti-globalization is that some countries involved in trade don't get corresponding benefits from this trade, just as the income distribution effect produced by international trade will bring different effects to both sides of trade. In the 1980s, there was a growing wage gap between high-educated and low-educated workers in America. At the same time, there is a phenomenon in some other developed countries: a large number of low-skilled workers lose their jobs, while the relative wages of low-skilled workers show a downward trend. As a result, the wage gap between low-skilled workers and high-skilled workers widens. Feenstra and Hanson made the empirical study for this phenomenon, the results showed that the United States has outsourced a large number of relatively low-tech industries to developing countries and kept relatively high-tech industries at home which increased the demand for high-skilled workers and reduced the demand for low-skilled workers, finally there would be some corresponding changes in their wages. To test whether the same phenomenon had occurred during the same period in developing countries, Feenstra and Hanson used the relevant data of the Mexican workers in the 1980s to make empirical test, and found that Mexico's border factories handled much of the outsourced production which was still high-tech for Mexico from the US. Therefore, a large number of high-skilled workers in Mexico are needed for employment and production which lead to the rising wages in the high-skilled field in Mexico and the bigger wage gap between high-skilled and low-skilled workers.

Since taking part in global trade, the income level of our domestic workers is rising with participating in the international trade, but the wage gap between high-skilled workers and low-skilled workers is widening. Xu and Li (2007) once studied the relationship between trade and wage gap and found that before 1997, the wage gap in China was very small, and after 1997, the wage gap in China expanded rapidly [1]. So this question is worth exploring in depth. According to research by Feenstra and Hanson, outsourcing is the major reason to explain the widening wage gap in trading countries. China has taken on a variety of production activities from developed countries because of its relatively low labor costs, particularly in manufacturing. Therefore, we choose the sample data of China's manufacturing industry to investigate the impact of international trade on the wage gap empirically. 


\section{Literature Review}

Since the 1980s, the wage gap between high-skilled workers and low-skilled workers has widened in the United States and other developed countries with the development of international trade, and even the employment rate and real wage level of low-skilled workers were declining. Is this phenomenon caused by international trade? This problem has aroused widespread concern among economists.

In theory, Feenstra and Hanson believed that developed countries keep the core link of the processing chain at home and outsource some low-end link to developing countries in order to save costs and increase profits, which resulted in relatively increased domestic demand for high-tech workers and relatively higher wages [2]. In terms of empirical test, Feenstra and Hanson (1995) mainly used the data of American manufacturing industry for regression test [3]. They used the method of estimating skilled labor to study the impact of outsourcing on the relative wage gap between skilled-workers and unskilled-workers by using the panel data of American manufacturing industry from 1979 to 1987. The results showed that outsourcing led to the increase in the relative wage of high-skilled workers by $15 \%-33 \%$.

After Feenstra and Hanson, other scholars used the same method to estimate the relative demand of skilled labor to test the impact of trade on wage gap in different countries empirically. Head and Ries (2000) used the micro data of 1070 Japanese manufacturing companies from 1965 to 1990 for regression analysis and found that the outsourcing of Japanese companies increased the relative demand and wage of domestic skilled labor [4]. Haskel and Slaughter (2001) made two-stage regression analysis with the data of British manufacturing industry from 1960 to 1990 and found that trade widened the income gap but had little impact [5]. Through the above empirical tests, we can draw the conclusion that trade increases both the relative demand and relative wage of skilled labor in developed countries.

Is the consistency of the test results affected by the test method? Some scholars tested the impact of international trade on the wage gap empirically by using the method of estimating the zero-profit condition. Feenstra and Hanson (1999) developed a two-stage regression method to estimate the impact of international outsourcing and technological progress on the wage gap between skilled and unskilled workers by using the zero-profit condition [6]. They made estimation on the American manufacturing and found that the contribution of international outsourcing to wage income gap is $15 \%$. Kuang-Chung HUS (2006) used the manufacturing data of the United States from 1970 to 1990 to analyze the wage gap in the US by the two-stage estimation method [2]. The results showed that in the 1970s, international outsourcing narrowed the wage gap between skilled workers and unskilled workers, while in the 1980s, international outsourcing widened the wage gap between skilled workers and unskilled workers. Different empirical methods and data may lead to inconsistent results. Therefore, com- 
prehensive factors should be taken into account in the empirical test and analysis of the relationship between trade and wage gap in developed countries to ensure the accuracy of the results.

These tests are analyses of developed countries and regions, so is the change of wage gap in developing countries the same as the outsourcing model analyzed by Feenstra (2003)? Feenstra and Hanson (1995) also took Mexico as the research object, and made statistics on the employment data of US-Mexico joint venture factories [7]. They found that the average annual growth rate of equipment employees was $10.2 \%$ from 1978 to 1983, and 15.9\% from 1983 to 1990. Robbins (1996) used the household survey data of nine developing countries from 1970 to 1990 to make regression analysis, and found that countries such as Argentina, Chile, Mexico's trade development made a sharp rise in the employment of high-skilled workers in various countries and the wages rise, which led to a widening income gap [8]. Xu and Li (2007) used a similar method to extract data from 1500 Chinese enterprises to study the impact of trade on China's wage gap and found that the development of trade has narrowed the wage gap between skilled workers and non-skilled workers [1]. There is no unified conclusion for the above empirical results. Therefore, further empirical test and analysis of developing countries are needed.

China is the largest developing country that participates in the international trade. The testing conclusions of China should have more typical significance. According to the conclusion, the test of China can be divided into the following three categories:

International trade widens the wage gap within the industry. Yu Mei-Ci (2008) used the panel data model from 2000 to 2005 to analyze the impact of foreign trade on the relative wage gap in 27 subsectors of China's manufacturing industry [9]. The results showed that international trade led to the expansion of the wage gap in the manufacturing industry, while export trade increased the wage gap in labor-intensive industries. Yang Chun-Yan (2012) used the panel data of 27 manufacturing industries from 1998 to 2008 for regression. She used the method of "panel corrected standard deviation" in order to reduce the deviation, and it was found that trade widened the wage gap through technological progress and labor productivity [10]. Wang Tao and Zhao Dan (2015) used the panel data to make regression analysis and analyzed the relationship between foreign trade and industry income gap of 19 industries in China from 2003 to 2012. The results showed that export expanded the income gap [11].

International trade narrows the wage gap within the industry. Yu Mei-Ci (2008) made the regression analysis of 27 manufacturing industry segments which are divided into labor intensive, capital intensive and technology intensive industries according to the characteristics of manufacturing industry [9]. The results showed that export trade led to a smaller wage gap in capital-intensive industries. Wang Tao and Zhao Dan (2015) conducted a regression analysis on the panel data of 19 industries from 2003 to 2012, and found that import trade 
would narrow the income gap among industries [11]. Yin Zheng and $\mathrm{Ni}$ Zhi-Wei (2018) estimated the wage levels of high-skilled workers and low-skilled workers by using the matching method, and conducted a regression analysis on the panel data of manufacturing enterprises from 2006 to 2016 [12]. The results showed that the wage gap between high-skilled workers and low-skilled workers presented a decreasing trend gradually.

International trade makes the wage gap vary over time. Chen Yi, Wang Hong-Liang et al. (2011) added labor supply and demand into the model of the impact of opening to the outside world on wage gap for research [13]. They made the regression analysis of panel data of 28 manufacturing subsectors from 1998 to 2006, it was found that the relative wage gap between skilled workers and unskilled workers in the manufacturing industry would first expand and then narrow which was inverted $\mathrm{u}$-shaped.

It shows that international trade have an effect which may be affected by data or testing method to wage gap is not only, we should take the change of the international world, the status of the national economy in the world, as well as the domestic economic development factors into consideration. In general, foreign trade needs to be divided into export trade and import trade for in-depth study and analysis. Due to the differences among manufacturing industries, the impact of trade on wage gap will also be different, and the impact may be non-linear. Therefore, it is necessary to distinguish the manufacturing industries. This paper uses systematic GMM method to study 26 manufacturing industries from 2003 to 2014 firstly, and then classifies them according to their different factor intensity to conduct an empirical study on the impact of trade on wage gap.

\section{Model Setting and Data Description}

\subsection{Specification of an Econometric Model}

We take Feenstra and Hanson's model as reference and use the proportion of the wages of high-skilled workers in the total wages as a measure of wage changes according to the research needs. This measure rises when the wages of high-skilled workers rise relative to those of low-skilled workers, indicating a wider wage gap between the two.

Suppose the production function of the enterprise is:

$$
Y_{n}=G_{n}\left(L_{n}, H_{n}, K_{n}, Z_{n}\right)
$$

where $n$ is the type of products, $Y_{n}$ is the total output of the industry, $K_{n}$ is the capital input of the industry, $H_{n}$ is the number of high-skilled workers, $L_{n}$ is the number of low-skilled workers, and $Z_{n}$ is other structural variables, such as import and export volume, technological progress and other factors. The cost function is:

$$
\begin{gathered}
C_{n}\left(W_{L}, W_{H}, K_{n}, Y_{n}, Z_{n}\right)=\min \left\{W_{L} L_{n}+W_{H} H_{n}\right\} \\
\text { st. } Y_{n}=G_{n}\left(L_{n}, H_{n}, K_{n}, Z_{n}\right)
\end{gathered}
$$


The cost function is transformed in the form of logarithm to obtain the proportion equation of the wage of high-tech workers in the total cost of the enterprise:

$$
\Delta S_{n H}=\alpha_{0}+\alpha_{K} \Delta \ln K_{n}+\alpha_{Y} \Delta \ln Y_{n}+\alpha_{Z} \Delta Z_{n}
$$

where $\Delta S_{n H}$ is the ratio of the salary of high-skilled workers to the total cost of the enterprise, which is used to reflect the wage gap between high-skilled workers and low-skilled workers. Considering the endogeneity of the explained variables, we can use the dynamic panel to for estimate and take the first-order lag of wage gap into account. At the same time, variables $Z_{n}$ including trade and technological progress which are added into the equation to construct the regression equation as follows:

$$
\begin{aligned}
W_{i t}= & \alpha_{i}+\beta_{1} W_{i t-1}+\beta_{2} \ln T R A D E_{i t}+\beta_{3} \ln T E C H_{i t} \\
& +\beta_{4} K_{i t}+\beta_{5} R C_{i t}+\beta_{6} \text { FIRM }_{i t}+\beta_{7} M R_{i t}+\varepsilon_{i t}
\end{aligned}
$$

Among them, $W$ represents the wage gap between high-skilled workers and low-skilled workers in the manufacturing sector, TRADE is the total amount of foreign trade of each industry, TECH indicates the degree of technological progress, $K$ is the physical capital intensity, $R C$ is the contribution rate of total assets, FIRM is openness to foreign country, $M R$ is the monopoly degree of the industry. In order to further analyze the impact of import and export on the wage gap within the industry, the foreign trade in the previous equation is decomposed into export trade and import trade, and the regression equation constructed is as follows:

$$
\begin{aligned}
W_{i t}= & \alpha_{i}+\beta_{1} W_{i t-1}+\beta_{2} \ln E X P O R T_{i t}+\beta_{3} \ln I M P O R T_{i t}+\beta_{4} \ln T E C H_{i t} \\
& +\beta_{5} K_{i t}+\beta_{6} R C_{i t}+\beta_{7} \text { FIRM }_{i t}+\beta_{8} M R_{i t}+\varepsilon_{i t}
\end{aligned}
$$

\subsection{Index Selection and Data Description}

1) The explained variable is the wage gap between high-skilled workers and low-skilled workers in the industry. As the country has not clearly defined the scope of high-skilled workers and low-skilled workers at present, this paper uses the method of Mei-Ci Yu (2008) for reference, and takes the ratio of the wage of those engaged in scientific and technological activities and the wage of those remaining engaged in non-scientific and technological activities as the indicator to measure the wage gap.

2) Major explanatory variables are total foreign trade, import trade and export trade. There is no direct way to obtain the import and export volume of manufacturing sub-industries. This paper refers to the corresponding table of international trade standard classification (SITC, Rev3) and China's national economy industry classification (GB/T4754-2002) provided by Sheng Bin (2002) [14]. We can get the import amount and export amount of commodities in 3-digit code of international trade standard classification from UN Comtrade Database, and then we can add the corresponding goods according to the classification of the industry to get total imports and total exports of the manufacturing sub-sector. 
Finally, thus dollar will be converted into RMB at the current exchange rate.

3) Control variables

Technological progress. In this paper, the scientific and technological activity personnel in the industry above the scale can be used to roughly measure the degree of technological progress. The more scientific and technological personnel in the industry, the higher the degree of technological progress.

Physical capital intensity. In this paper, the ratio of the net value of fixed assets in different industries to the total industrial output value is used to measure the physical capital intensity.

Total asset contribution rate. Measuring the economic profit level of each industry with the contribution rate of total assets.

The degree of opening to the outside world. In this paper, the ratio of the industrial output value of enterprises in the industry as "foreign-funded" enterprises and the total output value of various industries is used to measure the degree of opening up of the industry.

The degree of industry monopoly. This paper measures the degree of industry monopoly by the ratio of the average annual number of employees in state-owned units above the industry scale and the average annual number of employees in the industry.

In this regression model, all variables will appear as natural logarithms or ratios. Among the original data of the above indicators, the data of the average annual number of employees in the industry, the total industrial output value and the net value of fixed assets are from China statistical yearbook. The wage data are from China labor statistics yearbook. The data of science and technology activists are from the yearbook of science and technology of China. The relevant data of trade comes from UN Comtrade Database and is collected by author. Various data and calculation methods are shown in Table 1.

\section{Empirical Results and Analysis}

Based on the panel data of 26 manufacturing industries from 2003 to 2014, this paper analyzes the impact of trade on the wage gap between high-skilled workers and low-skilled workers. Considering the dynamic nature of wage change (Dai Feng, 2010), we can introduce the first-phase lag of wage gap and use the method of differential GMM and systematic GMM to estimate [15]. GMM method starts from the moment condition and constructs the equation with parameters. It does not need to assume the distribution of variables, nor does it need to know the distribution information of random disturbance terms. It can solve the endogeneity problem that may exist in explanatory variables effectively. First, we estimate the overall manufacturing industry and the estimated results are shown in Table 2.

GMM is established on the premise that there is no second-order and higher autocorrelation in the residual sequence of the difference equation for the consistency of estimation, and the instrumental variables are strictly exogenous, so 
Arellano-Bond sequence correlation test and Sargan test are required for the estimated results. The null hypothesis tested by AR (2) is that there is no second-order sequence correlation in the residual sequence of the difference equation. If the corresponding $\mathrm{P}$ value is greater than 0.1 , it means that the null hypothesis is accepted at the significance level of $10 \%$. In other words, there is no second-order sequence correlation in the residual sequence of the difference equation. In Table 2, whether it is AR (1) or AR (2), the result of P value indicates that the difference equation has only first-order sequence correlation, but no second-order sequence correlation. The model passes the test of autocorrelation. The results of Sargan test show that all the instrumental variables are valid. The model has passed Arellano-Bond sequence correlation test and Sargan test, so the estimation results of differential GMM and system GMM are consistent and reliable. The same is true for the model in Table 4.

Table 1. A statistical description of the sample $(2003-2014 \mathrm{~N}=26$ industry $\mathrm{T}=12$ year $\mathrm{NT}=312)$.

\begin{tabular}{|c|c|c|c|c|c|c|}
\hline Variable name & $\begin{array}{l}\text { Variable } \\
\text { meaning }\end{array}$ & Counting methods & Mean & $\begin{array}{l}\text { Standard } \\
\text { deviation }\end{array}$ & Minimum & Maximum \\
\hline$W$ & Relative wage gap & $\begin{array}{l}\text { The ratio of the wages } \\
\text { of high-skilled workers } \\
\text { to those of low-skilled } \\
\text { workers }\end{array}$ & 1.5895 & 0.4244 & 0.8382 & 3.8792 \\
\hline Intrade & Total foreign trade & $\begin{array}{l}\text { Take the } \\
\text { logarithm of total } \\
\text { foreign trade }\end{array}$ & 16.9908 & 1.6747 & 12.4529 & 19.8422 \\
\hline $\ln$ export & Export trade & $\begin{array}{l}\text { Take the logarithm } \\
\text { of total export trade }\end{array}$ & 16.3367 & 2.0182 & 8.2820 & 19.4236 \\
\hline $\ln$ import & Import Trade & $\begin{array}{l}\text { Take the logarithm } \\
\text { of total import trade }\end{array}$ & 15.7799 & 1.8373 & 10.5431 & 19.2012 \\
\hline $\ln t e c h$ & Technical progress & $\begin{array}{l}\text { Personnel engaged in } \\
\text { science and technology } \\
\text { activities in industries } \\
\text { above designated size }\end{array}$ & 10.5974 & 1.2778 & 6.8916 & 13.1334 \\
\hline$K$ & $\begin{array}{l}\text { Physical capital } \\
\text { intensity }\end{array}$ & $\begin{array}{l}\text { The proportion of } \\
\text { net fixed assets in the } \\
\text { total industrial } \\
\text { output value }\end{array}$ & 0.2526 & 0.1006 & 0.1104 & 0.6363 \\
\hline$R C$ & $\begin{array}{c}\text { Total asset } \\
\text { contribution rate }\end{array}$ & China Statistical Yearbook & 0.1713 & 0.1280 & 0.0216 & 0.8683 \\
\hline FIRM & $\begin{array}{l}\text { Openness to foreign } \\
\text { country }\end{array}$ & $\begin{array}{l}\text { The proportion of } \\
\text { the total output value } \\
\text { of foreign-funded } \\
\text { enterprises in the total } \\
\text { industrial output value }\end{array}$ & 0.3064 & 0.1766 & 0.0002 & 0.9957 \\
\hline$M R$ & Industry monopoly & $\begin{array}{l}\text { The ratio of the number } \\
\text { of employees of state-owned } \\
\text { enterprises above designated } \\
\text { size to the number of } \\
\text { employees in their respective } \\
\text { industries }\end{array}$ & 0.1037 & 0.1502 & 0.0022 & 0.8907 \\
\hline
\end{tabular}


Table 2. A test of the impact of international trade on the wage gap between high-skilled and low-skilled workers.

\begin{tabular}{|c|c|c|c|c|}
\hline \multirow[b]{2}{*}{ Estimation method } & \multicolumn{2}{|c|}{ Model 1} & \multicolumn{2}{|c|}{ Model 2} \\
\hline & Diff-GMM & Sys-GMM & Diff-GMM & Sys-GMM \\
\hline L. $w$ & $\begin{array}{l}-0.0193 \\
(-1.120)\end{array}$ & $\begin{array}{c}0.423^{* * *} \\
(15.38)\end{array}$ & $\begin{array}{l}-0.0308 \\
(-1.582)\end{array}$ & $\begin{array}{c}0.222^{* * *} \\
(8.145)\end{array}$ \\
\hline $\ln$ trade & $\begin{array}{c}-0.233^{* * *} \\
(-4.652)\end{array}$ & $\begin{array}{c}-0.203^{* * *} \\
(-6.578)\end{array}$ & & \\
\hline $\ln$ export & & & $\begin{array}{c}-0.142^{\star * *} \\
(-4.363)\end{array}$ & $\begin{array}{c}-0.205^{* * *} \\
(-3.857)\end{array}$ \\
\hline $\ln$ import & & & $\begin{array}{l}-0.0411 \\
(-0.996)\end{array}$ & $\begin{array}{l}0.250^{* * *} \\
(5.754)\end{array}$ \\
\hline $\ln t e c h$ & $\begin{array}{c}-0.398^{* * *} \\
(-9.636)\end{array}$ & $\begin{array}{c}-0.0915^{* * *} \\
(-4.054)\end{array}$ & $\begin{array}{c}-0.432^{\star * *} \\
(-9.555)\end{array}$ & $\begin{array}{c}-0.397^{* * *} \\
(-10.00)\end{array}$ \\
\hline k & $\begin{array}{c}-0.757^{* * *} \\
(-5.989)\end{array}$ & $\begin{array}{l}-0.993^{* * *} \\
(-4.346)\end{array}$ & $\begin{array}{l}-0.588^{* *} \\
(-2.502)\end{array}$ & $\begin{array}{c}-0.966^{* * *} \\
(-4.461)\end{array}$ \\
\hline rc & $\begin{array}{c}0.263 \\
(1.071)\end{array}$ & $\begin{array}{c}1.768^{* * *} \\
(5.083)\end{array}$ & $\begin{array}{l}0.0641 \\
(0.339)\end{array}$ & $\begin{array}{c}0.965^{* * *} \\
(3.551)\end{array}$ \\
\hline firm & $\begin{array}{c}0.612^{* * *} \\
(3.377)\end{array}$ & $\begin{array}{c}1.210^{* * *} \\
(5.330)\end{array}$ & $\begin{array}{l}0.502^{* *} \\
(2.299)\end{array}$ & $\begin{array}{l}1.603^{* * *} \\
(15.15)\end{array}$ \\
\hline $\mathrm{mr}$ & $\begin{array}{l}-0.0373 \\
(-0.234)\end{array}$ & $\begin{array}{c}-0.763^{* * *} \\
(-3.096)\end{array}$ & $\begin{array}{c}-0.137 \\
(-1.628)\end{array}$ & $\begin{array}{c}-1.233^{* * *} \\
(-2.812)\end{array}$ \\
\hline cons & $\begin{array}{c}9.829^{* * *} \\
(16.67)\end{array}$ & $\begin{array}{c}5.580^{* * *} \\
(11.32)\end{array}$ & $\begin{array}{c}9.189^{* * *} \\
(14.26)\end{array}$ & $\begin{array}{l}4.880^{* * *} \\
(9.542)\end{array}$ \\
\hline $\operatorname{AR}(1)$ & 0.0181 & 0.0029 & 0.0179 & 0.0036 \\
\hline $\operatorname{AR}(2)$ & 0.2010 & 0.9638 & 0.1694 & 0.5233 \\
\hline Sargan test & 0.6655 & 0.9490 & 0.6028 & 0.9409 \\
\hline Observed value & 260 & 286 & 260 & 286 \\
\hline
\end{tabular}

Notes: (1) ${ }^{* * *},{ }^{* *}$ and ${ }^{*}$ are respectively significant at the level of $1 \%, 5 \%$ and $10 \%$ (both sides), and the Numbers in brackets are the corresponding standard error(both sides); (2) AR (1), AR (2) and Sargan test respectively provide the $\mathrm{P}$ value of the test; (3) L. w represents a period of lag in the wage gap. The same below.

However, there are differences between differential GMM and system GMM. Compared with differential GMM, system GMM can better solve the problem of weak instrumentality. System GMM can set up the difference equation and the original horizontal equation together to form the system of equations, and use the lag term of the variable as the tool of the corresponding variable of the difference equation, and the lag term of the difference variable as the tool of the corresponding variable of the horizontal equation. Therefore, the estimation efficiency of the system GMM is higher than that of the differential GMM, and the standard error obtained by the two-step estimation can significantly reduce the 
estimation deviation in the case of small samples and the weak instrumental variable problem of the horizontal lag term in the short panel data model. In view of this, this paper mainly analyzes the two-step estimation results of the GMM system, and lists the estimation results of the differential GMM model as a reference.

The systematic GMM estimation results of model1 in Table 2 show that trade has a significant negative impact on the wage gap, which to some extent indicates that trade narrows the wage gap within the industry in China. It can be seen from the GMM estimation results of model 2 that the impact of export and import on the wage gap is different, and both pass the significance test at the level of $1 \%$. Export trade narrows the wage gap between high-skilled workers and low-skilled workers, the reason may be that: our country joins the trade in the form of processing trade, and many export sectors of manufacturing absorb large Numbers of low-skilled workers for production activities which rise the relative wages for low-skilled workers (Sheng Bin and Ma Tao, 2008), narrowing the wage gap [16]. Import trade widens the wage gap between high-skilled and low-skilled workers and imports a large number of intermediate products. On the one hand, low-priced intermediate products reduce the demand for low-skilled workers in production departments (Sheng Bin, 2009). On the other hand, Grossman and Helpman (1991) believe that technology progress can be obtained by using advanced intermediate products from abroad, and import can increase the demand for high-skilled workers through technology spillover [17]. So the wage gap widens. Technological progress narrows the wage gap, indicating that China's technological progress is capital-saving and requires the replacement of capital factors with labor factors for production, which increases the demand for ordinary workers and leads to the narrowing of the wage gap between high-skilled and low-skilled workers. Physical capital intensity has a significant negative effect on the wage gap between high-skilled and low-skilled workers, that is, the wage gap narrows, which is consistent with the results of the study of Yu Mei-Ci (2008). The contribution rate of total assets has a significant positive impact on the wage gap between high-skilled and low-skilled workers. In other words, the higher the profit rate of the industry is, the larger the wage gap between low-skilled and high-skilled workers is. The degree of opening to the outside world has a significant positive impact on the relative wage gap, indicating that the deeper an enterprise is involved in trade, the greater the wage gap between high-skilled workers and low-skilled workers will be. The fundamental goal of foreign investment in China is to bypass trade barriers and gain a larger market share in China's market (Zhang Jian-Wei, 2017) [18]. Such foreign investment is prone to technology spillovers and increases the demand for high-skilled workers, thus widening the wage gap. The monopoly degree of an industry has a significant negative impact on the relative wage gap between high-skilled and low-skilled workers. To some extent, the higher the monopoly degree of an industry is, the smaller the wage gap will be. The result is not in line 
with expectations because the industry monopoly index in this paper is expressed by the ratio of state-owned employees to all employees rather than the proportion of the income of state-owned enterprises. Moreover, the degree of monopoly of each subsector of China's manufacturing industry is generally low and the difference is not large, and the flow of labor between industries is relatively easy. The higher the level of monopoly, the more state-owned employees it needs and the more ordinary skilled workers it will absorb, resulting in a smaller wage gap within the industry.

In the previous empirical test on the trade and wage gap with all the samples, we assume that all industries are basically homogeneous. In fact, we ignore the specific characteristics of different manufacturing industries, which will lead to differences in the impact of trade on the wage gap within the industry. Due to the limitation of sample size and the need of GMM method, this paper classifies 26 manufacturing industries into labor intensive and capital intensive according to Sheng Bin's (2002) classification because of the limitation of sample size and the need of GMM method (see Table 3 for details) [14]. We use GMM method to test labor-intensive industries and capital-intensive industries respectively, and the results are shown in Table 4. In view of the above mentioned problem, system GMM can reduce the deviation of small samples and solve the problem of weak instrumental variables comparing with differential GMM, so we mainly analyze the system GMM based on the two-step estimation results and also list the results of differential GMM as a reference.

It turns out that trade has different effects on industries with different characteristics. In terms of labor-intensive industries, both exports and imports have a negative impact on the wage gap at the significance level of 5\%. According to the Stolper-Samuelson Theorem, export will increase the demand for abundant elements, and low-skilled labor is exactly the abundant elements of labor-intensive industries in China. That is, the wage of low-skilled labor will be relatively increased, so the wage gap will be narrowed. Our country's labor-intensive industries import a large number of intermediate products, which require more low-skilled labor force to carry out production activities. These activities will create lots of job opportunities that can absorb many rural surplus labor forces, so the wages of low-skilled workers get improved relatively and the wage gap will narrow. In terms of capital-intensive industries, Export trade has a negative impact on the wage gap and import trade has a positive impact on the wage gap, but neither is notable. Technological progress has a negative impact on the wage gap in capital-intensive industries when the level of significance is $5 \%$. This shows that the development of this type of industry requires not only a large amount of capital input, but also the participation of ordinary labor. The ability of workers to conduct the work is not very high and more low-skilled workers will join the ranks of capital-intensive industries, so technological progress will narrow the wage gap between high-skilled and low-skilled workers. These suggest that capital-intensive industries are more affected by technological progress, while trade is less important than technological progress. 
Table 3. Statistical description of major variables in different industries.

\begin{tabular}{ccccccc}
\hline & $\begin{array}{c}\text { Variable } \\
\text { name }\end{array}$ & $\begin{array}{c}\text { Observed } \\
\text { value }\end{array}$ & Mean & $\begin{array}{c}\text { Standard } \\
\text { deviation }\end{array}$ & Minimum & Maximum \\
\hline \multirow{5}{*}{ Labor-intensive } & $\mathbf{w}$ & 144 & 1.6344 & 0.3487 & 0.8382 & 2.6708 \\
& $\begin{array}{l}\text { ln export } \\
\text { ln import }\end{array}$ & 144 & 15.6958 & 2.3766 & 8.2820 & 18.5572 \\
& 144 & 14.5722 & 1.6333 & 10.5431 & 17.1131 \\
& ln tech & 144 & 9.6767 & 0.9751 & 6.8916 & 11.6107 \\
& $\mathbf{w}$ & 168 & 1.5510 & 0.4775 & 0.9714 & 3.8792 \\
Capital-intensive & $\ln$ export & 168 & 16.8861 & 1.4460 & 11.8504 & 19.4236 \\
& $\ln$ import & 168 & 16.8149 & 1.2910 & 13.7362 & 19.2012 \\
& $\ln$ tech & 168 & 11.3866 & 0.9323 & 9.4516 & 13.1335 \\
\hline
\end{tabular}

Note: calculated by the author.

Table 4. The estimated results of different factor intensive industries.

\begin{tabular}{|c|c|c|c|c|}
\hline \multirow[b]{2}{*}{ Estimation method } & \multicolumn{2}{|c|}{ Labor-intensive } & \multicolumn{2}{|c|}{ Capital-intensive } \\
\hline & Diff-GMM & Sys-GMM & Diff-GMM & Sys-GMM \\
\hline \multirow[t]{2}{*}{ L. w } & 0.643 & $0.898^{\star * *}$ & 0.0921 & -0.0197 \\
\hline & $(1.326)$ & $(3.122)$ & $(0.966)$ & $(-0.261)$ \\
\hline \multirow[t]{2}{*}{ ln export } & -0.312 & $-0.542^{\star *}$ & -0.0628 & -0.0414 \\
\hline & $(-1.630)$ & $(-2.135)$ & $(-0.587)$ & $(-0.344)$ \\
\hline \multirow[t]{2}{*}{$\ln$ import } & -0.828 & $-2.524^{* *}$ & -0.0701 & 0.0632 \\
\hline & $(-1.496)$ & $(-2.559)$ & $(-1.146)$ & $(0.549)$ \\
\hline \multirow[t]{2}{*}{$\ln t e c h$} & 0.902 & $1.574^{\star *}$ & $-0.350^{\star * \star}$ & $-0.226^{\star *}$ \\
\hline & $(1.000)$ & $(2.157)$ & $(-3.011)$ & $(-2.192)$ \\
\hline \multirow[t]{2}{*}{ k } & -2.265 & $-2.787^{\star *}$ & 0.176 & $1.227^{*}$ \\
\hline & $(-1.449)$ & $(-2.566)$ & $(0.258)$ & $(1.840)$ \\
\hline \multirow[t]{2}{*}{$\mathrm{rc}$} & -13.96 & $-5.383^{\star *}$ & -0.0258 & 0.693 \\
\hline & $(-1.129)$ & $(-2.441)$ & $(-0.0481)$ & $(0.766)$ \\
\hline \multirow[t]{2}{*}{ firm } & -13.10 & $-9.084^{\star * *}$ & 0.106 & $2.476^{* * *}$ \\
\hline & $(-1.233)$ & $(-2.646)$ & $(0.0911)$ & $(3.163)$ \\
\hline \multirow[t]{2}{*}{$\mathrm{mr}$} & $7.479^{*}$ & 4.239 & 0.322 & -0.0605 \\
\hline & $(1.673)$ & $(1.470)$ & $(0.611)$ & $(-0.104)$ \\
\hline \multirow[t]{2}{*}{ cons } & $15.95^{* * *}$ & $34.56^{* * *}$ & $7.428^{* * *}$ & $2.651^{*}$ \\
\hline & $(2.721)$ & $(3.190)$ & $(3.445)$ & $(1.657)$ \\
\hline $\operatorname{AR}(1)$ & 0.005 & 0.085 & 0.0304 & 0.0241 \\
\hline $\operatorname{AR}(2)$ & 0.773 & 0.230 & 0.2326 & 0.8586 \\
\hline Sargan test & 0.9996 & 1.0000 & 0.9958 & 1.0000 \\
\hline Observed value & 120 & 132 & 140 & 154 \\
\hline
\end{tabular}

Notes: (1) ${ }^{* * *},{ }^{*}$ and $*$ are respectively significant at the level of $1 \%, 5 \%$ and $10 \%$ (both sides), and the Numbers in brackets are the corresponding standard error (both sides); (2) AR (1), AR (2) and Sargan test respectively provide the $\mathrm{P}$ value of the test. 


\section{Conclusions and Suggestions}

To raise the income, narrow the income gap and make the benefits of participating in international trade available to everyone is a major development issue of reform and opening up and the basis for promoting social harmony and stability. This paper uses the panel data of 26 manufacturing industries from 2003 to 2014 to analyze the impact of trade on the wage gap within the industry theoretically, and also constructs the dynamic panel model to test the impact of trade on the wage gap empirically. We divide the manufacturing industry into labor intensive industry and capital intensive industry that can be used to analyze the differences in the income distribution effect of foreign trade among the industries according to Sheng Bin's (2002) classification of the industry because of the differences in the industry. The important findings are as follows: 1) In terms of the manufacturing sector as a whole, export trade narrows the wage gap. The reason may be that export trade gives full play to our comparative advantage, and specialized production requires more low-skilled labor, so the wages of the low-skilled workers get improved. Import trade widens the wage gap. The reason may be that, on the one hand, the factor substitution effect of import trade reduces the demand for low-skilled labor; on the other hand, the technology spillover makes the industry prefer skilled labor. 2) Because there are differences in the industry, we divide the industry into labor intensive industry and capital and technology intensive industry according to the factor intensity and analyze the impact of trade on the wage gap of different industries deeply. After the empirical test, we find that: In terms of labor-intensive industries, both import trade and export trade narrow the wage gap. The reason may be that the products of labor-intensive industries are still at the low end of the value chain, and more low-skilled workers are needed. In terms of capital-intensive industries, the wage gap is more affected by technological progress than by trade.

Governments, enterprises and skilled workers can take some actions from the above conclusions:

First, our government should take advantage of its comparative advantages to actively participate in international division of labor and develop import and export trade, especially export trade, which help our domestic enterprises to accumulate capital, improve economic efficiency, and increase the wages of enterprise employees. The government can also take some effective measures for export enterprises, such as increasing the demand for ordinary labor through the effect of industrial agglomeration, so that low-skilled labor can enjoy the benefits of international trade.

Second, enterprises should take some measures to deal with different problems. Since labor-intensive industries mainly participate in the international intra-product trade in the form of processing trade, import trade will rely on foreign technology to the detriment of its own technical level. We need to learn advanced technologies from foreign countries, strive to improve the quality of products in labor-intensive industries, and seize an advanced position in the in- 
ternational market. In this way, the negotiation ability between China and other countries will be enhanced, the progress of domestic industries will be promoted, and the economic competitiveness of China will be strengthened. Capital-intensive industries should maintain their advantages and increase the use of low-skilled workers, thus helping to narrow the wage gap.

Third, high-skilled workers and low-skilled workers should improve their own quality. While low-skilled workers currently benefit from intra-product trade in some industries, such as processing in labor-intensive industries, which cannot be sustained for long. On the one hand, we cannot always rely on the traditional comparative advantage to survive in the international market because of the increasingly fierce competition in the international market, and countries like India and Vietnam are catching up with us in terms of labor advantage, so we need to nurture new technologies. On the other hand, China's technology is constantly improving and its industry is constantly upgrading, which makes the position of China's manufacturing industry rise in the international division of labor, therefore, more high-skilled workers are needed at the high end of the product production value chain. In order to meet the market demand for high-skilled workers and improve China's position in the international competition, we need to strengthen education, carry out skills training for employees, and develop on-the-job education and other activities.

\section{Conflicts of Interest}

The author declares no conflicts of interest regarding the publication of this paper.

\section{References}

[1] Xu, B. and Wei, L. (2007) Trade, Technology, and China's Wage Inequality. China Europe International Business School, Mimeo.

[2] Feenstra, R.C. and Hanson, G.H. (1997) Productivity Measurement and the Impact of Trade and Technology on Wages: Estimates for the U.S., 1972-1990. NBER Working Paper No. 6052.

[3] Feenstra, R.C. and Hanson, G.H. (1995) Foreign Investment, Outsourcing and Relative Wages. NBER Working Paper No. 5121. https://doi.org/10.3386/w5121

[4] Geishecker, I. and Gorg, H. (2005) Do Unskilled Workers Always Lose from Fragmentation? The North American Journal of Economics and Finance, 16, 81-92. https://doi.org/10.1016/j.najef.2004.11.002

[5] Goldberg, P.K. and Pavcnik, N. (2007) Distributional Effects of Globalization in Developing Countries. NBER Working Paper 12885.

https://doi.org/10.3386/w12885

[6] Feenstra, R.C. and Hanson, G.H. (1996) Globalization, Outsourcing and Wage Inequality. NBER Working Paper 5424.

[7] Feenstra, R.C. and Hanson, G.H. (1995) Foreign Direct Investment and Relative Wages: Evidence from Mexico's Maquiladoras. NBER Working Paper, No. 5122. https://doi.org/10.3386/w5122

[8] Robbins, D. (1996) Evidence on Trade and Wages in the Developing World. OECD Technical Papers NO. 119. 
[9] Yu, M.-C. (2008) The Effect of International Trade and Technology Change on Relative Wage Gap: An Empirical Study Based on China's Manufacturing Data. Journal of International Trade, 4, 9-15.

[10] Yang, C.-Y. (2012) Trade Openness and Wage Gap: An Empirical Study Based on Manufacturing Sector's Panel Data. World Economy Studies, 7, 41-45.

[11] Wang, T. and Zhao, D. (2015) Foreign Trade and Industry Income Gap: Based on China's Provincial Panel Data. Inquiry into Economic Issues, 5, 107-111.

[12] Yin, Z, and Ni, Z.-W. (2018) Export Trade, Technical Progress and Wage Inequality. Journal of Industrial Technological Economics, 4, 85-91.

[13] Chen, Y., Wang, H.-L. and Wang, X.-Q. (2011) Openness and Manufacturing Wage Gap in China: An Empirical Study Based on Labor Supply and Demand Model. Finance and Trade Research, 1, 8-18.

[14] Sheng, B. (2002) Political and Economic Analysis of China's Foreign Trade Policies. San Lian Publishing House, Shanghai.

[15] Dai, F. (2010) Analysis on FDI and Regional Income Inequality of China Based on Factor Endowments: Evidence from Dynamic Panel Data Model with GMM Estimation. Journal of International Trade, 5, 79-87.

[16] Sheng, B. and Ma, T. (2008) Impact of Trade in Intermediate Products on Changes in China's Labor Demand: An Analysis Based on Dynamic Panel Data from the Industrial Sector. The Journal of World Economy, 3, 12-20.

[17] Grossman, G.M. and Helpman, E. (2013) Matching and Sorting in a Global Economy. NBER Working Paper 19513.

[18] Zhang, J.-W. (2017) The Impact of Foreign Investment on the Wage Gap: Based on China's Industrial Sector Analysis. The World of Survey and Research, 2, 34-39. 